
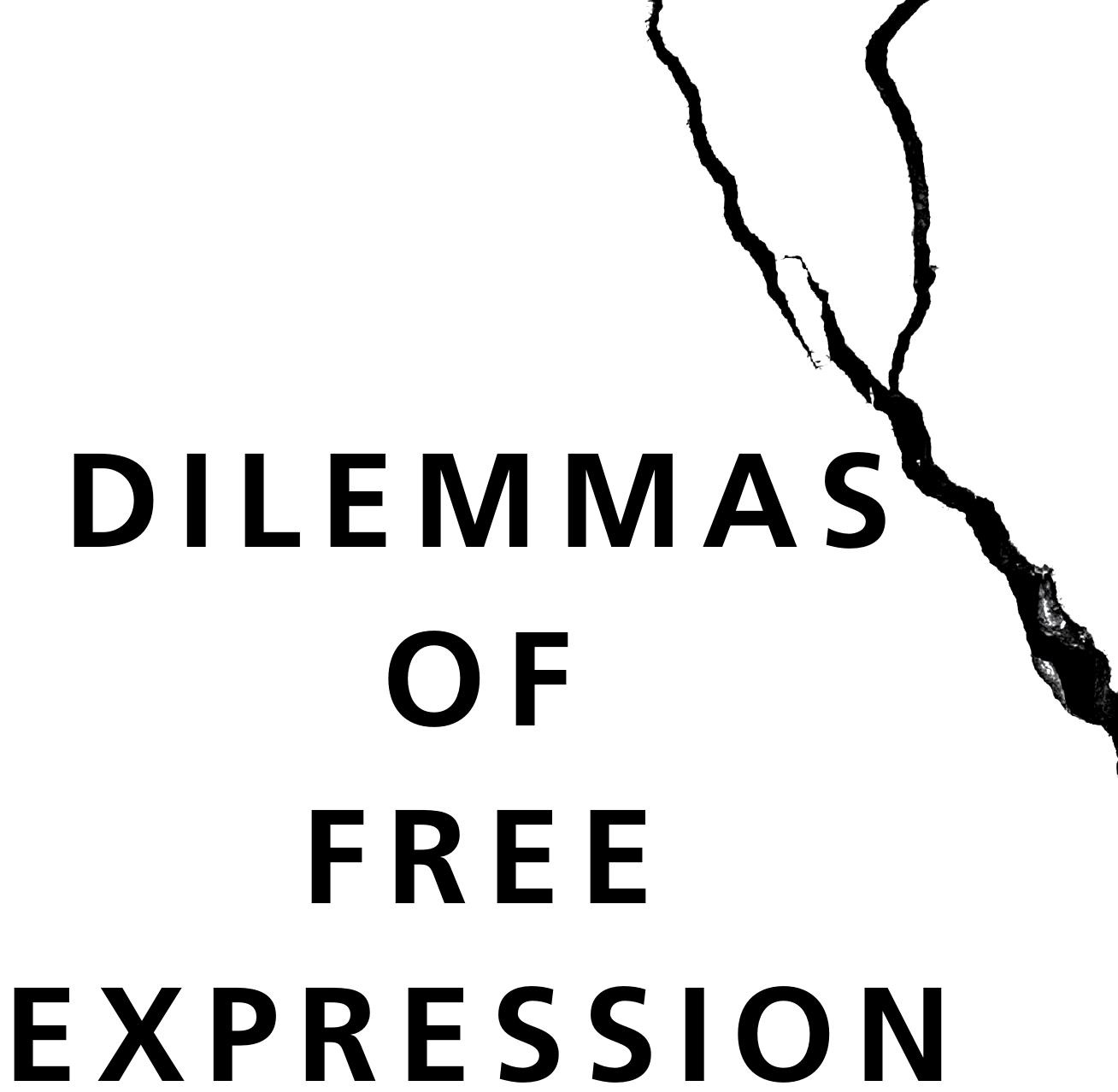

\author{
EDITED BY \\ EMMETT MACFARLANE
}

UNIVERSITY OF TORONTO PRESS

Toronto Buffalo London 


\title{
DILEMMAS OF FREE EXPRESSION
}

\author{
Edited by Emmett Macfarlane
}

Free expression is under threat. Social media and "fake news," misinformation, and disinformation have prompted governments to propose new forms of regulation that are deeply challenging to free expression. Hate speech, far-right populism, campus speech debates, and censorship consistently make headlines in Canada and abroad.

Dilemmas of Free Expression evaluates the ways to confront challenging moral issues, policy problems, and controversies that pay heed to the fundamental right to free expression. The essays in this volume offer timely analyses of legal, policy, and philosophical challenges, as well as social repercussions to our understanding of expressive freedom in relation to government obligations and public discourse.

Free expression and its limits are multifaceted, deeply complex, inherently values-based, and central to the ability of a society to function. Dilemmas of Free Expression addresses the challenges of limiting free expression across a host of issues through analyses by leading and emerging voices in a number of disciplines, including political science, law, philosophy, and Indigenous studies.

emmett macfarlane is an associate professor in the Department of Political Science at the University of Waterloo. 
(C) University of Toronto Press 2022

Toronto Buffalo London

utorontopress.com

Printed in the U.S.A.

ISBN 978-1-4875-2929-1 (cloth) ISBN 978-1-4875-2932-1 (EPUB)

ISBN 978-1-4875-2930-7 (paper) ISBN 978-1-4875-2931-4 (PDF)

\section{Library and Archives Canada Cataloguing in Publication}

Title: Dilemmas of free expression / edited by Emmett Macfarlane.

Names: Macfarlane, Emmett, editor.

Description: Includes bibliographical references and index.

Identifiers: Canadiana (ebook) 20210313250 | Canadiana (print) 20210313145 |

ISBN 9781487529321 (EPUB) | ISBN 9781487529314 (PDF) | ISBN 9781487529307

(paper) | ISBN 9781487529291 (cloth)

Subjects: LCSH: Freedom of expression - Canada.

Classification: LCC KE4418.D55 2022 | LCC KF4483.C524 D55 2022 kfmod |

DDC 342.7108/53-dc23

This book has been published with the help of a grant from the Federation for the Humanities and Social Sciences, through the Awards to Scholarly Publications Program, using funds provided by the Social Sciences and Humanities Research Council of Canada.

University of Toronto Press acknowledges the financial assistance to its publishing program of the Canada Council for the Arts and the Ontario Arts Council, an agency of the Government of Ontario.
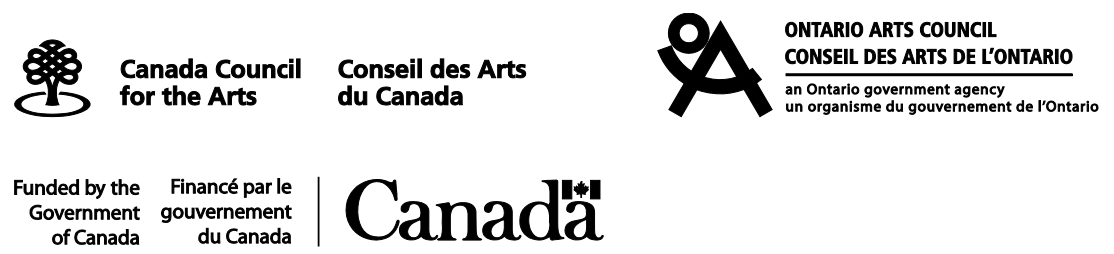
This page intentionally left blank 